\title{
PENGEMBANGAN BAHAN AJAR KIMIA RINTISAN SMA BERTARAF INTERNASIONAL KELAS XI MATERI LAJU REAKSI
}

\author{
Inova Putri Carera \\ I Wayan Dasna (idasna@um.ac.id) \\ Jurusan Kimia FMIPA Universitas Negeri Malang
}

\begin{abstract}
This study was aimed to develop teaching materials about chemical reaction rate which covered materials adapted to A-Level High School students of grade XI in Pioneer International Standard High School (RSMA-BI). The developmental research was adopting the instructional development model 4D which include four stages of development, namely define, design, develop, and disseminate. Instructional materials were written in English consist of seven topics titled: Reaction Rate Concept, The Exchange's Expressions, Rate Law and Reaction Order, Experimental Determination of a Rate Law, Reaction Mechanism, Theories of Reaction Rate, Factors Affecting Reaction Rate. Results of content validation from content experts obtained the average score of 3. 56 of 1-4 range of scores which means valid / good / decent. Test limited to high school students of RSBI obtained an average score of 3.35 (valid / good / decent). The results of the use of teaching materials obtained a score of 77.8 which is above the minimal passing grade (75). Therefore it can be concluded that the materials were feasible to be used in the classroom.
\end{abstract}

Keywords: chemical reaction rate teaching materials, Pioneer International Standard High School (RSMA-BI)

\section{ABSTRAK}

Penelitian ini bertujuan untuk mengembangkan bahan ajar laju reaksi dengan cakupan materi yang disesuaikan dengan A-Level untuk siswa kelas XI Rintisan Sekolah Menengah Atas Bertaraf Internasional (RSMA-BI. Rancangan penelitian pengembangan mengadaptasi model pengembangan bahan ajar Model $4 \mathrm{D}$ yang meliputi empat tahap pengembangan, yaitu define, design, develop dan disseminate. Produk pengembangan adalah bahan ajar kimia RSMA-BI kelas XI materi laju reaksi yang ditulis dalam bahasa Inggris menggunakan pendekatan kontekstual. Bahan ajar terdiri atas empat bagian utama yaitu pendahuluan, materi, evaluasi dan penutup. Materi tersusun atas tujuh sub materi yaitu Reaction Rate Concept, The Rate's Expressions, Rate Law and Reaction Order, Experimental Determination of a Rate Law, Reaction Mechanism, Theories of Reaction Rate, Factors Affecting Reaction Rate. Hasil validasi isi dari ahli materi diperoleh nilai rata-rata 3,56 dari rentang skor 1-4 dengan kriteria valid/baik/layak. Hasil uji terbatas pada siswa SMA RSBI diperoleh nilai rata-rata 3,35 dari rentang skor 1-4 dengan kriteria valid/baik/layak. Hasil uji penggunaan bahan ajar diperoleh skor sebesar 77,8. Skor ini diatas SKM (Skor Kelulusan Minimal) yaitu 75 sehingga dapat disimpulkan bahwa bahan ajar telah layak dan dapat digunakan dalam pembelajaran di kelas.

Kata kunci: bahan ajar, laju reaksi, rintisan SMA bertaraf Internasional (RSMA-BI) 
Beberapa sekolah menengah di Indonesia, khususnya di Kota Malang sedang melaksanakan amanat Undang-Undang Republik Indonesia Nomor 20 Tahun 2003 tentang Sistem Pendidikan Nasional, Pasal 50, ayat (3) dengan mengembangkan SMA bertaraf internasional, RSMA-BI. Berdasarkan buku Panduan Penyelenggaraan Program RSMA-BI (2009:9), RSMA-BI atau Sekolah Bertaraf Internasional (SBI) adalah sekolah yang sudah melampaui seluruh SNP (Standar Nasional Pendidikan) yang diperkaya dengan keunggulan mutu tertentu yang berasal dari negara maju sehingga lulusannya memiliki mutu/kualitas berstandar nasional dan sekaligus bertaraf internasional. RSMA-BI menggunakan kurikulum KTSP plus dimana Standar Kompetensi (SD) dan kompetensi dasar (KD) tiap-tiap matapelajaran pada KTSP diadaptasi sehingga sesuai dengan kedalaman dan keluasan materi sekolah luar negeri yang digunakan rujukan (mother school). Oleh sebab itu, materi pelajaran Kimia pada RSMA-BI mempunyai keluasan dan kedalaman materi yang berbeda dengan sekolah reguler yang menggunakan KTSP. Salah satu kompetensi dasar pada matapelajaran kimia yang dibelajarkan pada siswa kelas XI adalah laju reaksi. Materi laju reaksi dalam RSMA-BI diharapkan setara dengan materi yang diajarkan pada pada sekolah-sekolah yang ada di negara maju, setidaknya setara dengan materi yang ada pada jenjang A-Level (Brigg, 2008; Chemistry Insight, 2007). Perbandingan konten materi laju reaksi KTSP dan A-Level (Earl \& Wilford, 2006; Harwood, 2008) menunjukkan bahwa materi laju reaksi pada KTSP lebih rendah daripada materi pada A-Level sehingga perlu diperluas dan diperdalam.

Dalam proses pembelajaran, salah satu bagian penting dari pelaksanaan RSBI pada semua tingkatan sekolah adalah ketersediaan bahan ajar. Khususnya, untuk matapelajaran kimia, buku ajar yang dijual secara komersial sangat bervariasi. Beberapa buku ajar menggunakan dwi bahasa sehingga teks yang berbahasa Inggris tidak dimanfaatkan sepenuhnya oleh siswa. Buku ajar yang lain, keseluruhannya menggunakan Bahasa Inggris namun masih sulit dipahami oleh siswa karena penyajian materi kimia cenderung informatif dan deskriptif.

Berdasarkan karakteristik pebelajar RSBI, buku ajar yang diperlukan siswa tidak sematamata deskriptif dan informatif namun harus dapat mendorong siswa untuk belajar dan mengembangkan kemampuan berpikir tingkat tinggi. Paparan pada bahan ajar hendaknya dapat memicu rasa ingin tahu siswa sehingga terjadi proses konstruksi konsep dari kegiatan mempelajari buku tersebut. Di samping itu, karena siswa RSBI didorong juga menguasai bahasa asing sebagai salah satu keunggulan maka buku ajar harus dibuat dalam Bahasa Inggris namun struktur bahasanya yang sederhana sehingga mudah dipelajari siswa. Untuk memperoleh bahan ajar kimia yang khas untuk membelajarkan kimia di SMA RSBI, pada penelitian ini dikembangkan model buku ajar materi laju reaksi untuk siswa SMA kelas XI.

Buku ajar untuk materi laju reaksi yang tersedia di pasaran sangat bervasiasi dalam urutan, kedalaman, dan keluasan materi. Pengkajian tentang keluasan dan kedalaman materi laju reaksi dilaksanakan pada empat buku teks yang beredar di kota Malang yaitu (A) Buku teks Kimia 2 SMA dan MA untuk Kelas XI (Rachmawati \& Johari, 2006); (B) Buku teks Chemistry for Senior High School (Justiana \& Muchtaridi , 2006); (C) Buku teks Cerdas Belajar Kimia untuk Kelas XI SMA/MA Program IPA (Sutresna, 2007) dan (D) Buku Teks A-Level Chemistry For Senior High School Students Volume 2A (Effendy,2007). Dari hasil pengkajian tersebut diketahui bahwa pada buku (A), (B) dan (C) belum ditemukan secara eksplisit paparan tentang konsep laju reaksi rata-rata (average rate) dan konsep laju reaksi terhadap (rate with respect to), informasi mengenai satuan yang dipakai pada konstanta laju (rate constant, $k$ ), konsep integrated law (meliputi konversi ekspersi laju ke bentuk laju terintegrasi, grafik konsentrasi-waktu untuk setiap orde reaksi, penentuan konstanta laju dari slope), konsep waktu paruh (half-life) untuk orde reaksi 1, 2, dan nol, konsep molekularitas 
dalam mekanisme reaksi, dan reaksi katalisis $\mathrm{Fe}^{3+}$ dalam $\mathrm{S}_{2} \mathrm{O}_{8}{ }^{2-}$. Sementara buku (D) memuat penjelasan konsep-konsep tersebut. Berdasarkan data tersebut masih diperlukan perbaikan untuk bahan ajar materi laju reaksi baik dari segi variasi, keluasan dan kedalaman materi. Pada penelitian ini, bahan ajar yang disusun diharapkan dapat digunkan sebagai alternatif buku teks pelajaran kimia laju reaksi yang sesuai dan memadai untuk menjelaskan konsep laju reaksi dalam proses pembelajaran di RSMA-BI. Materi ini dipilih karena berhubungan dengan aplikasi dalam kehidupan sehari-hari khususnya di bidang industri dan banyak berkaitan dengan materi lain sehingga siswa perlu memahami konsep-konsep yang terdapat pada materi laju reaksi dengan mudah, mendalam dan sesuai dengan perkembangan teknologi.

Pada pengembangan bahan ajar kimia RSMA-BI materi laju reaksi yang akan dikembangkan mamakai kurikulum Cambridge (A-Level) yang dikombinasikan dengan KTSP. Pemilihan kurikulum dari Cambridge (A-level) karena kurikulum ini merupakan pengayaan dengan standar negara maju yang dapat berupa penyesuaian, penguatan, pengayaan, pengembangan, perluasan, dan pendalaman pada peningkatan mutu pendidikan.

Pengembangan bahan ajar merujuk pada model-model pengembangan yang ada seperti Borg \& Gall (1987), Dick \& Carey (1978), Thiagarajan (1974), dan lain-lain (dalam Trianto, 2010; Tuckman,1978). Pada pengembangan bahan ajar ini digunakan model pengembangan Thiagarajan karena paling relevan untuk pengembangan bahan ajar kimia materi laju reaksi. Model pengembangan Thiagarajan sering disebut model 4D karena mencakup 4 tahap pengembangan yaitu define, design, develop, dan disseminate. Pada tahap define peneliti mengembangkan konsep rancangan bahan ajar yang akan dibuat berdasarkan masalah yang terkait dengan bahan ajar yang ada dan spesifikasi bahan ajar yang dibutuhkan oleh pengguna. Setelah mendefinisikan bentuk akhir dari bahan ajar yang akan dikembangkan, selanjutnya peneliti membuat rancangan (design) pengembangan yang berupa epitom-epitom konsep-konsep yang menggambarkan urutan, keluasan, dan kedalaman materi. Tahap berikutnya dilakukan pengembangan (develop) dengan menggunakan rujukan-rujukan yang relevan. Urutan paparan materi kimia pada umumnya dimulai dari penyajian fakta, dilanjutkan dengan penjelasan konseptual, dan diakhiri dengan penyajian simbolik berupa rumus, reaksi, atau gambar untuk memformulasikan fakta dan konsep. Bagian akhir dari pengembangan dilakukan uji validitas atau kelayakan yang meliputi kelayakan isi dan kelayakan penyajian.

Berdasarkan uraian tersebut tujuan dari penelitian ini adalah untuk mengembangkan bahan ajar kimia materi laju reaksi siswa kelas XI R-SMA-BI dengan model pengembangan 4-D. Hasil pengembangan diharapkan dapat digunakan untuk membelajarkan kimia dalam bahasa Inggris pada siswa kelas XI RSMA-BI khususnya materi laju reaksi.

\section{METODOLOGI}

Penelitian menggunakan rancangan pengembangan Thiagarajan (1974) yang mencakup tahap-tahap pengembangan 4D (define, design, develop, dan disseminate). Secara garis besar, prosedur pengambangan disajikan dalam Gambar 1 berikut.

Tahap pertama pendefinisian (define) meliputi lima langkah, yaitu (1) analisis ujung depan, menganalisis masalah dasar yang dihadapi dalam pembelajaran kimia materi laju reaksi pada RSMA-BI. Ketersediaan buku teks pelajaran kimia yang mendukung pencapaian kompetensi siswa yang mengacu pada kurikulum yang dipakai di RSMA-BI sangat sedikit variasinya serta terdapat keterbatasan pada keluasan dan kedalaman materi pada buku teks kimia yang telah ada (dengan KTSP). Oleh karena itu perlu dikembangkan bahan ajar baru yang memenuhi tuntutan kompetensi 
dari kurikulum yang dipakai pada pembelajaran kimia RSMA-BI seperti pada A-Level; (2) analisis siswa, dilihat dari kemampuan berpikir siswa yaitu secara umum kemampuan berpikir siswa SMA adalah termasuk dalam perkembangan intelektual operasional formal dimana pemikiran siswa tidak hanya terbatas pada benda-benda atau peristiwa-peristiwa yang konkret dalam memecahkan suatu permasalahan melainkan mampu berpikir secara abstrak; (3) analisis tugas, merinci komponen inti/materi laju reaksi yang akan dikembangkan dalam bahan ajar dengan mengkaji SK dan KD pada Kurikulum 2006 (KTSP) dan Content pada Kurikulum Cambridge; (4) analisis konsep, membuat peta konsep sehingga tampak gambaran keluasan dan kedalaman materi laju reaksi dalam bahan ajar dan; (5) perumusan spesifikasi bahan ajar, menentukan komponen yang dicantumkan dalam bahan ajar.

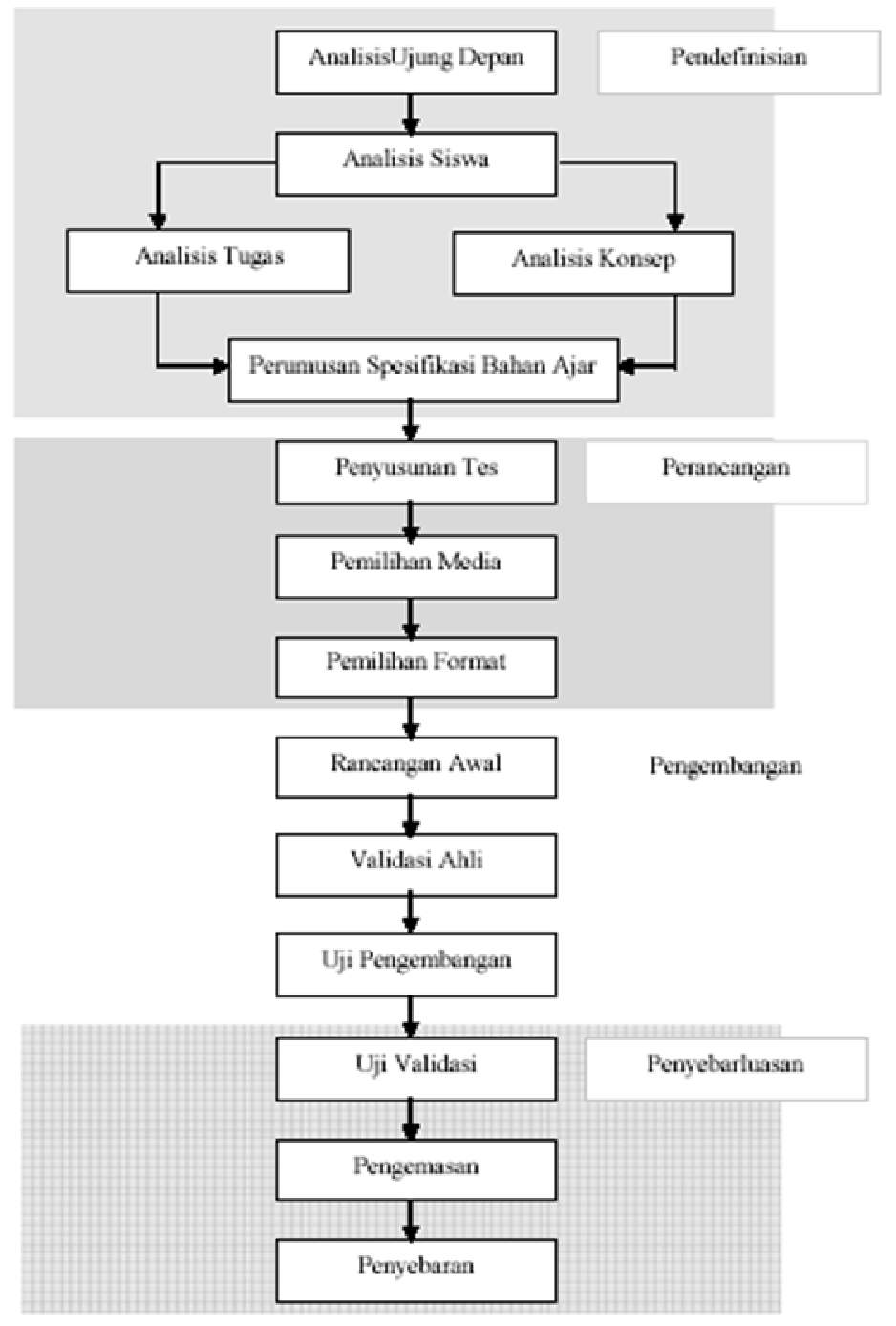

Gambar 1. Model Pengembangan 4D 
Tahap kedua, perancangan (design), yaitu penyiapan prototipe bahan ajar laju reaksi yang dilakukan melalui tiga langkah (1) penyusunan tes acuan patokan, terdiri atas soal-soal yang secara langsung mengukur kemampuan siswa seperti yang telah ditentukan dalam perumusan indikator pencapaian hasil belajar materi laju reaksi pada RSMA-BI dari aspek kognitif; (2) pemilihan media, bahan ajar yang dikembangkan disajikan dalam bentuk media cetak yaitu buku teks; (3) pemilihan format, mengikuti model pengembangan bahan ajar Dick dan Carey (1978).

Tahap ketiga, pengembangan (develope), dilakukan revisi terhadap prototipe bahan ajar atas masukan dari para ahli (validator) sehingga menghasilkan bahan ajar yang lebih baik. Tahap ini terdiri dari tiga langkah (1) validasi bahan ajar, melibatkan beberapa ahli untuk mengevaluasi bahan ajar yang telah dikembangkan berdasarkan butir instrumen penilaian bahan ajar yang telah disusun oleh pengembang; (2) simulasi, mengoperasionalkan bahan ajar yang dikembangkan kepada beberapa siswa namun dalam proses tidak dilakukan oleh peneliti; (3) uji coba terbatas, uji coba dari bahan ajar yang telah direvisi sebelumnya yang dilihat melalui tanggapan dan reaksi dari beberapa siswa RSMA-BI kelas XI program IPA.

Tahap keempat, penyebarluasan (disseminate), tidak dilaksanakan karenakan keterbatasan waktu peneliti dalam menyusun bahan ajar, sehingga tidak ada pembahasannya.

Produk penelitian dan pengembangan pada materi laju reaksi telah direvisi berdasarkan data hasil validasi isi dan uji terbatas, serta masukan atau penilaian tambahan dari kedua uji yang dilaksanakan adalah paket buku teks untuk siswa kelas XI di RSMA-BI pada materi laju reaksi.

\section{HASIL}

Buku teks siswa kelas XI di RSMA-BI dapat digunakan oleh guru sebagai buku teks alternatif dan dapat digunakan oleh siswa sebagai sumber belajar dalam proses pembelajaran bersama di kelas maupun mandiri.

Buku teks laju reaksi yang dihasilkan ditulis dengan menggunakan bahasa Inggris yang secara keseluruhan terdiri dari 54 halaman. Penggunaan buku teks dapat dilakukan secara linear atau runut sesuai dengan urutan yang disajikan ataupun secara acak berdasarkan kebutuhan dan keinginan pengguna. Buku teks terdiri atas empat bagian utama yaitu pendahuluan, materi, evaluasi dan penutup. Pertama, pendahuluan yang terdiri atas (a) sampul, yang memuat judul, sasaran/pengguna, kurikulum yang dipakai, gambar pengembangan, nama dosen pembimbing pengembang dan nama pengembang; (b) kata pengantar, berisi tujuan dilakukannya pengembangan bahan ajar menggunakan kurikulum yang dipakai pada RSMA -BI; (c) petunjuk penggunaan buku, berisi uraian singkat mengenai fungsi bagian-bagian pada buku teks sehingga pengguna dapat menggunakan buku teks secara optimal; (d) standard isi KTSP, dicantumkan Standar Kompetensi (SK) dan Kompetensi Dasar (KD) materi laju reaksi yang terdapat pada Kurikulum 2006, KTSP.; (e) indikator, pengetahuan dan ketrampilan yang akan dicapai pada materi laju reaksi; (f) peta konsep, memberi gambaran kepada siswa mengenai keluasan dan kedalaman materi; $(\mathrm{g})$ daftar isi.

Kedua, materi terdiri atas tujuh materi pokok (a) Reaction Rate Concept; (b) The Rate's Expresssion; (c) Rate Law and Reaction Order (d) Experimental Determination of a Rate Law; (e) Reaction Mechanism; (f) Theories of Reaction Rate; (g) Factors Affecting Reaction Rate. Perumusan materi laju reaksi kedalam tujuh materi pokok didasarkan pada keluasan dan kedalaman konsep yang saling berhubungan. Penyajian tiap materi pokok dilengkapi dengan (1) Concept, memberikan informasi atau konsep yang telah dipelajari sebelumnya untuk memudahkan siswa dalam mengingat materi yang telah diajarkan sehingga membantu siswa memahami materi yang baru; (2) Think Time, berisi pertanyaan yang mengarahkan siswa untuk dapat menemukan konsep yang terkadang tidak 
diuraikan pengembang secara langsung dan membutuhkan informasi tambahan dari sumber lain; (3) Chemistry Adventure, berisi situs web yang berkaitan dengan pengetahuan tambahan atau animasi untuk membantu visualisasi siswa dalam memahami materi; (4) Illustration, berisi gambar yang mengaitkan materi dengan kehidupan sehari-hari; (5) Question, untuk mengevaluasi pemahaman siswa pada materi yang telah diajarkan.

Bagian ketiga dan keempat merupakan evaliasi dan penutup. Bagian ini terdapat pada akhir materi dan dilengkapi (1) Resume, berisi inti dari uraian materi secara keseluruhan; (2) Evaluation, untuk mengevaluasi pemahaman siswa terhadap keseluruhan materi; (3) Key Term, untuk memudahkan siswa dalam pencarian istilah penting serta disertakan; (4) References, berisi sumber pustaka yang sesuai dengan perkembangan ilmu.

Materi pokok I adalah Reaction Rate Concept, siswa diarahkan untuk mampu mendefiniksikan pengertian laju reaksi. Awalnya siswa diarahkan untuk membaca tabel perubahan konsentrasi penguraian $\mathrm{N}_{2} \mathrm{O}_{5}$ dilanjutkan dengan membaca grafik pada halaman selanjutnya. Think Time yang terdapat disebelah grafik ditujukan agar siswa mampu mendefinisikan pengertian laju reaksi dengan menjawab pertanyaan yang terdapat di dalamnya. Di bawah grafik perubahan konsentrasi peruraian $\mathrm{N}_{2} \mathrm{O}_{5}$ terhadap waktu dijelaskan kemiringan garis pada konsentrasi reaktan dan produk. Penjelasan ini dimaksudkan agar siswa memahami bahwa semakin curam kemiringan garis maka laju reaksi semakin besar. Concept berisi informasi mengenai Molaritas disertakan di sebelah definisi laju reaksi karena satuan laju reaksi adalah M/s maka siswa diharapkan mampu mengingat pengertian molaritas, satuan dan perhitungannya. Think Time diberikan setelah konsep molaritas agar siswa mengingat salah satu contoh perhitungan yang berhubungan dengan konsep molaritas. Perhitungan laju rata-rata disampaikan dengan melakukan perhitungan laju perubahan konsentrasi penguraian $\mathrm{N}_{2} \mathrm{O}_{5}$ pada jangka waktu setiap 100 detik. Pada buku teks, dilakukan perhitungan selama tiga selang waktu. Concept berisi rumus perhitungan laju rata-rata diberikan agar memudahkan siswa mengingat rumusnya. Sementara Think Time diberikan agar siswa mencoba menghitung laju rata-rata dari reaksi yang diberikan. Setelah seluruh konsep pada materi pokok ini disampaikan, siswa dapat menguji pemahamannya dengan mengerjakan soal pada Question.

Materi pokok II adalah The Rate's Expresssion, siswa diharapkan dapat menyimpulkan hubungan koefisien reaksi dengan laju reaksi. Pada buku teks, siswa ditunjukkan hubungan antara persamaan reaksi yang memiliki koefisien reaksi yang sama dengan laju reaksi kemudian hubungan persamaan reaksi dengan koefisien reaksi yang bervariasi dengan laju reaksi. Contoh reaksi yang memiliki koefisien reaksi bervariasi adalah $\mathrm{N}_{2} \mathrm{O}_{5}$, pada buku teks siswa diarahkan untuk menjelaskan hubungan koefisien reaksi dengan laju reaksi dan menghitung laju reaksi zat yang lain jika laju reaksi salah satu zat diketahui. Concept yang diberikan berisi informasi mengenai penulisan ekspresi laju untuk laju reaksi rata-rata dan laju reaksi sesaat. Pemberian Concept ini dimaksudkan agar siswa dapat membedakan aplikasi ekspresi laju diantara keduanya. Think Time diberikan bertujuan untuk menguji pemahaman siswa mengenai ekspersi laju (The Rate's Expression) sebelum siswa mengerjakan Question.

Materi pokok III adalah Rate Law and Reaction Order, siswa diarahkan untuk dapat menjelaskan komponen-konponen yang terdapat pada persamaan laju dan mengklasifikasikan orde reaksi. Pada buku teks, siswa diperkenalkan dengan persamaan umum laju reaksi. Masing-masing komponen pada persamaan laju dijabarkan dan dijelaskan kepada siswa bahwa perolehan persamaan laju adalah berdasarkan data eksperimen yang dicontohkan oleh persamaan laju penguraian $\mathrm{N}_{2} \mathrm{O}_{5}$ dan pembentukan $\mathrm{NO}_{2}$. Concept berisi informasi mengenai persamaan laju ditujukan agar siswa mengtahui bahwa laju reaksi bergantung pada konsentrasi reaktan. Hubungan 
orde reaksi dan laju perubahan dijelaskan melalui diagram. Diagram diberikan dengan tujuan agar siswa dapat menentukan besar perubahan laju $[A]$ dengan orde reaksi A yang berbeda-beda, jika sebelumnya diketahui bahwa $[A]$ adalah dua. Think Time diberikan dengan tujuan untuk mengevaluasi pemahaman siswa mengenai hubungan orde reaksi dan laju perubahan. Pada akhir materi pokok diberikan soal latihan, Question untuk mengevaluasi pemahaman siswa.

Materi pokok IV adalah Experimental Determination of a Rate Law, siswa diarahkan untuk dapat menentukan persamaan laju reaksi berdasarkan data eksperimen. Awalnya, siswa diajarkan untuk menghitung orde reaksi dari data percobaan. Terdapat dua metode penentuan orde reaksi yaitu metode laju awal (initial rates metod) dan laju terintegrasi (integrated rate law). Pada penentuan orde reaksi dengan metode laju awal, diberikan data percobaan reaksi oksidasi ion iodida oleh hidrogen peroksida dalam suatu larutan asam yang diketahui konsentrasi awal $\mathrm{H}_{2} \mathrm{O}_{2}$ dan I- serta laju awal pembentukan $\mathrm{I}_{3}$. Selanjutnya dijelaskan kepada siswa perhitungan mencari masing-masing orde reaksi untuk $\mathrm{H}_{2} \mathrm{O}_{2}$ dan $\mathrm{I}$. Persamaan laju dapat ditentukan setelah semua orde reaksi diketahui. Selain menentukan orde reaksi, konstanta laju ( $k$ ) dapat ditentukan. Nilai konstanta laju $(k)$ adalah sama untuk semua percobaan dengan catatan persamaan laju yang telah ditentukan sebelumnya adalah benar. Concept, dicantumkan disebelah perhitungan konstanta laju dimaksudkan untuk mempermudah siswa dalam mengingat rumus konstanta laju rata-rata. Tabel satuan untuk konstanta laju ( $k$ ) diberikan untuk menunjukkan pada siswa bahwa satuan konstanta laju ( $k$ ) bergantung pada orde reaksi. Think Time, berisi pertanyaan mengenai perbedaan laju reaksi $(r)$ dan konstanta laju $(k)$. Pertanyaan tersebut dimaksudkan agar siswa dapat menjelaskan bahwa laju reaksi $(r)$ bergantung pada konsentrasi reaktan dan satuan laju reaksi $(r)$ selalu M/s. Sementara konstanta laju $(k)$ tidak bergantung pada konsentrasi melainkan pada suhu dan satuan konstanta laju $(k)$ bergantung pada orde reaksi.

Sebelum memasuki penentuan orde reaksi dengan metode laju terintegrasi (integrated rate law), diberikan penjelasan bahwa dengan menggunakan laju terintegrasi, perubahan konsentrasi reaktan atau produk disepanjang waktu reaksi dapat diketahui. Persamaan laju terintegrasi merupakan persamaan yang menggambarkan hubungkan konsentrasi reaktan terhadap waktu sehingga diperlukan konversi dalam persamaan integral dari persamaan laju. Pada buku teks, orde reaksi yang dibahas hanya meliputi orde reaksi nol, satu dan dua. Pembahasan orde reaksi nol dimulai denga memberikan contoh reaksi berorde nol kepada siswa yaitu reaksi penguraian amonia $\left(\mathrm{NH}_{3}\right)$ yang dituliskan ekspresi lajunya. Selanjutnya siswa diarahkan untuk memahami grafik konsentrasi $\mathrm{NH}_{3}$ terhadap laju reaksi. Berdasarkan pembacaan grafik, siswa diharapkan dapat menjelaskan bahwa pada orde reaksi nol, laju reaksi tidak bergantung pada konsentrasi reaktan. Perlu dilakukan konversi dari ekspresi laju penguraian $\mathrm{NH}_{3}$ ke persamaan laju terintegrasi yang melibatkan serangkaian operasi integral matematika. Untuk membantu siswa melakukan konversi, pada Concept diberikan rumus umum pengintegralan. Persamaan laju terintegrasi serupa dengan persamaan linear sehingga nilai konstanta laju $(k)$ dapat dihitung dari kemiringan garis (slope) pada grafik konsentrasi-waktu untuk orde reaksi nol. Pemahanan mengenai waktu paruh, dipelajari setelah penentuan konstanta laju ( $k$ ) dari grafik grafik konsentrasi-waktu untuk orde reaksi nol. Hal ini dikarenakan, waktu paruh untuk reaksi berorde nol bergantung pada nilai konstanta laju $(k)$ dan konsentrasi reaktan. Selanjutnya Chemistry Adventure, diberikan agar siswa dapat memperlajari pengertian laju reaksi sampai penentuan orde reaksi dari sumber lain menggunakan internet melalui situs yang diberikan. Urutan penyajian untuk orde reaksi satu dan dua dalam buku teks serupa dengan penyajian untuk orde reaksi nol. 
Materi pokok V adalah Reaction Mechanism, siswa diharapkan dapat membedakan reaksi yang terdiri dari satu tahapan (single-step reaction) dan banyak tahapan (multi-step reaction), dapat mengidentifikasi reaksi intermediet dan mampu menuliskan reaksi keseluruhan (overall reaction) berdasarkan reaksi yang diketahui serta mampu menentukan rate determining-step, yaitu laju dari reaksi elementer yang berjalan paling lambat. Awalnya, siswa diarahkan untuk mengamati reaksi yang terjadi antara 1-bromopropan dengan ion hidroksida yang terjadi pada satu tahap kemudian mengamati reaksi penguraian $\mathrm{N}_{2} \mathrm{O}$ yang terjadi dalam beberapa tahap. Reaksi yang terjadi pada penguraian $\mathrm{N}_{2} \mathrm{O}$ terdiri dari banyak reaksi elementer. Reaksi elementer yang terdapat pada reaksi tahapan banyak bergantung pada molekularitas. Pada pembahasan yang berhubungan dengan molekularitas, siswa diperkenalkan pada unimolecular reaction, bimolecular reaction serta termolecular reaction. Dari reaksi pada penguraian $\mathrm{N}_{2} \mathrm{O}$ siswa diarahkan untuk megidentifikasi reaksi intermediate dan menuliskan reaksi keseluruhan. Selanjutnya, setelah memahami konsep molekularitas, siswa diharapkan mampu menentukan persamaan laju dari reaksi elementer yang ada pada multi-step reaction. Penentuan rate determining-step diawali dengan menjabarkan mekanisme reaksi pada $\mathrm{N}_{2} \mathrm{O}$ yang diketahui cepat lambatnya reaksi elementer berlangsung. Pada uraian materi disampaikan kepada siswa bahwa rate determining-step ditentukan dari laju dari reaksi elementer yang berjalan paling lambat. Chemistry Adventure, diberikan agar siswa mendapatkan pengetahuan yang lebih mengenai mekanisme reaksi dan rate-determining step melalui situs yang diberikan. Selanjutnya, untuk mengevaluasi pemahaman siswa mengenai materi pokok ini guru dapat menginstruksi siswa untuk mengerjakan Question.

Materi pokok VI adalah Theories of Reaction Rate, teori laju reaksi meliputi teori tumbukan (collision theory) dan keadaan transisi (transition state). Pada pembelajaran mengenai teori tumbukan, awalnya diuraikan kepada siswa mengenai hasil eksperimen bahwa laju reaksi akan meningkat apabila suhu reaksi ditingkatkan. Dari fakta ini, siswa diarahkan untuk memahami bahwa syarat terjadinya reaksi adalah adanya tumbukan antar partikel reaktan. Selanjutnya, siswa diarahkan pada pemahaman mengenai orientasi partikel dan energi minimum terjadinya tumbukan. Concept, berisi diagram potensial energi reaksi endotermik dan eksotermik dicantumkan untuk mempermudah siswa mengingat perbedaan energi di antara keduanya. Think Time, yang diberikan bertujuan agar siswa dapat mengurutkan reaksi dari yang lambat menuju cepat berdasarkan perhitungan pada diagram potensial energi.

Materi pokok VII adalah Factors Affecting Reaction Rate, faktor-faktor yang mempengaruhi laju reaksi dijelaskan meliputi lima sub-materi pokok yaitu cahaya (light), konsentrasi (concentration), suhu (temperature), luas permukaan (surface area) dan katalis (catalyst). Masing-masing faktor dalam penjelasannya disertakan percobaan untuk mendukung pemahaman siswa, kecuali pada faktor cahaya dan katalis. Think Time, diberikan bertujuan agar siswa dapat menjelaskan aplikasi pengaruh suhu, konsentrasi, katalis dan luas permukaan dalam kehidupan sehari-hari. Chemistry Adventure, diberikan agar siswa dapat melihat animasi sehubungan dengan faktor-faktor yang mempengaruhi laju reaksi melalui situs yang diberikan (Harwood and McMahon, 1997; McMurry and Fay, 2006).

Hasil validasi paket bahan ajar diperoleh nilai rata-rata 3,56 dengan kriteria valid/baik/layak. Berdasarkan hasil uji terbatas, diperoleh nilai nilai rata-rata 3,35 dengan kriteria valid/baik/layak untuk bahan ajar. Keefektifan bahan ajar yang dilakukan atas skor tes prestasi belajar dengan menggunakan bahan ajar tersebut memperoleh skor sebesar 77,8 diatas SKM (Skor Kelulusan Minimal) yaitu 75. Oleh karena itu, dapat disimpulkan bahwa paket bahan ajar kimia RSMA-BI kelas 
XI pada materi laju reaksi sudah layak dan dapat dilanjutkan untuk validasi empirik (evaluasi sumatif) di lapangan.

\section{PEMBAHASAN}

Berdasarkan hasil validasi isi dan uji terbatas terhadap buku ajar Kimia untuk materi poko laju reaksi yang dikembangkan diketahui bahwa hasil pengembangan termasuk kategori layak untuk digunakan. Dengan arti lain, bahwa isi buku ajar tersebut telah sesuai dengan kurikulum yang digunakan untuk RSBI (KTSP plus), urutan, kedalaman, dan keluasan materi sudah memadari digunakan oleh subyek belajar.

Karakteristik dari hasil pengembangan yang berbeda dengan buku ajar yang lain adalah: paparan dimulai dari penyajian fakta yang biasa diamati siswa dalam kehidupan sehari-hari (kontekstual), dari fakta tersebut kemudian diurai untuk mengetahui konsep-konsep yang terkait, dan pada bagian akhir baru disajikan simbol/rumus-rumus yang terkait dengan konsep. Model paparan yang demikian dapat meningkatkan motivasi dan hasil belajar siswa (Trowbridge,1990; Harwood et al, 1997; Yuliati et al, 2011). Sebagai contoh dalam memperkenalkan laju reaksi siswa diberikan beberapa fakta yang mengalami proses perubahan (Gambar 2). Berdasarkan fakta tersebut kemudian dikenalkan istilah laju perubahan yang melibatkan kuantitas zat pada keadaan awal dan yang bereaksi dalam satuan waktu tertentu. Dari deskripsi tersebut kemudian siswa diajak menganalisis data kuantitatif tentang perubahan konsentrasi $\mathrm{N}_{2} \mathrm{O}_{5}$ dalam wadah tertutup pada rentangan waktu berdasarkan reaksi:

$$
2 \mathrm{~N}_{2} \mathrm{O}_{5} \rightarrow \mathrm{NO}_{2}+\mathrm{O}_{2}
$$

Berdasarkan data yang disajikan siswa kemudian menginterpretasikan grafik antara konsentrasi terhadap waktu. Berdasarkan data tersebut siswa dapat menganalisis perubahan konsentrasi awal dan akhir terhadap waktu. Dari proses data tersebut siswa dapat mengkonstruksi konsep ungkapan laju yang dinyatakan dalam selisish reaktan per satuan waktu, konsep $-\mathrm{d}\left[\mathrm{N}_{2} \mathrm{O}_{5}\right] / \mathrm{dt}$, dan sebagainya.

Penyajian tiap materi pokok dalam bahan ajar ini dilengkapi dengan (1) Concept, memberikan informasi atau konsep yang telah dipelajari sebelumnya untuk memudahkan siswa dalam mengingat materi yang telah dipelajari sehingga membantu siswa memahami materi yang baru; (2) Think Time, berisi pertanyaan yang mengarahkan siswa untuk dapat menemukan konsep yang terkadang tidak diuraikan pengembang secara langsung dan membutuhkan informasi tambahan dari sumber lain; (3) Chemistry Adventure, berisi situs web yang berkaitan dengan pengetahuan tambahan atau animasi untuk membantu visualisasi siswa dalam memahami materi; (4) Illustration, berisi gambar yang mengaitkan materi dengan kehidupan sehari-hari; (5) Question, untuk mengevaluasi pemahaman siswa pada materi yang telah diajarkan. Mengevaluasi pemahaman siswa pada materi yang telah diajarkan. 
Think about the following reactions:

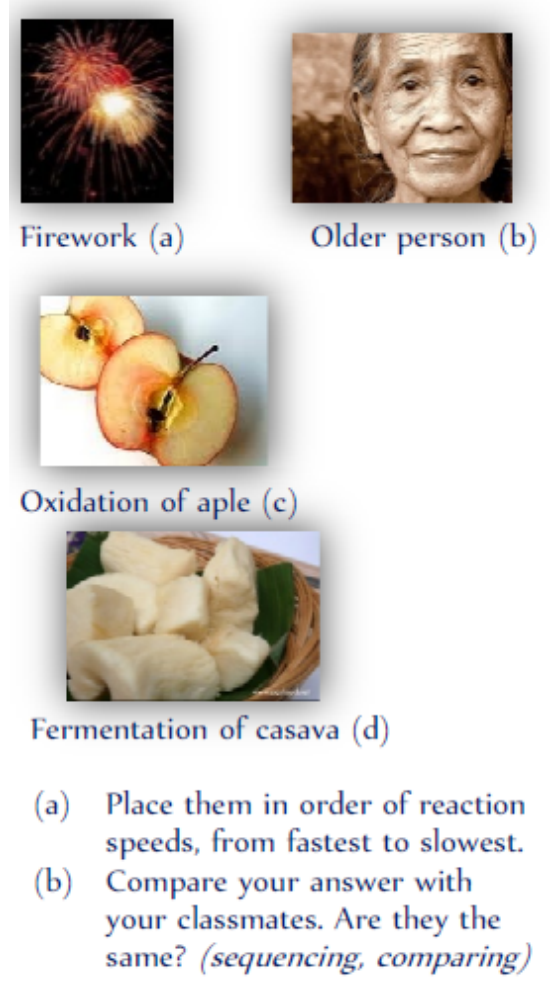

Gambar 2 Contoh pengenalan fakta

Produk dari pengembangan adalah paket bahan ajar kimia RSMA-BI kelas XI materi laju reaksi dapat digunakan untuk siswa dan guru. Buku teks laju reaksi dikembangkan mengikuti tahaptahapan model pengembangan 4-D. Paparan bahan ajar ditulis menggunakan bahasa Inggris yang secara keseluruhan terdiri dari 54 halaman. Buku teks terdiri atas empat bagian utama yaitu pendahuluan, materi, evaluasi dan penutup. Materi tersusun atas tujuh sub materi yaitu Reaction Rate Concept, The Rate's Expressions, Rate Law and Reaction Order, Experimental Determination of a Rate Law, Reaction Mechanism, Theories of Reaction Rate, Factors Affecting Reaction Rate. Penjabaran materi laju reaksi pada buku teks yang dihasilkan meliputi definisi laju reaksi, penentuan persamaan laju reaksi, penentuan orde reaksi, hubungan teori tumbukan dengan faktor-faktor yang mempengaruhi laju reaksi, pengaruh katalis dan mekanisme reaksi serta aplikasi penerapan konsep laju reaksi dalam kehidupan sehari-hari. Selain itu dijabarkan pula konsep laju reaksi rata-rata (average rate), informasi satuan yang dipakai pada konstanta laju (rate constant, $k$ ), integrated law (meliputi konversi ekspersi laju ke bentuk integrated law, grafik konsentrasi-waktu untuk setiap orde reaksi, penentuan konstanta laju dari slope), waktu paruh (half-life) untuk orde reaksi 1, 2 dan nol, molekularitas dalam mekanisme reaksi,dan reaksi katalisis $\mathrm{Fe}^{3+}$ dalam $\mathrm{S}_{2} \mathrm{O}_{8}{ }^{2-}$. Konsep-konsep pada buku teks ini menyediakan pengetahuan atas konsep-konsep yang diharapkan dicapai oleh siswa seperti yang tertuang pada kurikulum Cambridge A-Level. Buku teks juga dilengkapi dengan situs web untuk meningkatkan pemahaman siswa terhadap materi. Hasil pengembangan telah dinyatakan valid nilai rata-rata 3,56 dengan kriteria valid/baik/layak dan keefektifan bahan ajar yang dilakukan 
atas skor tes prestasi belajar dengan menggunakan bahan ajar tersebut memperoleh skor sebesar 77,8 diatas SKM (Skor Kelulusan Minimal) yaitu 75.

\section{KESIMPULAN DAN SARAN}

Bahan ajar yang telah dikembangkan diharapkan dapat bermanfaat bagi siswa terutama dalam kegiatan pembelajaran di kelas. Adapun saran untuk mengantisipasi keterbatasan paket bahan ajar diantaranya a) selama proses pembelajaran materi laju reaksi, guru dapat menggunakan bahan ajar yang telah dikembangkan sebagai sumber belajar dalam kegiatan pembelajaran sesuai dengan Rencana Pelaksanaan Pembelajaran (RPP) yang disusun oleh guru; b) bahan ajar yang telah dikembangkan dapat dijadikan sebagai buku tugas siswa untuk dikerjakan di rumah sehingga pada saat pembelajaran di kelas dapat dilakukan kegiatan diskusi untuk mengukur pemahaman siswa. Selain itu, perlu dilakukan studi lapangan untuk mengetahui efektivitas bahan ajar hasil pengembangan dalam pembelajaran materi laju reaksi sesuai dengan tuntutan kurikulum RSMA-BI.

\section{REFERENSI}

Briggs, J.G.R. (2008). Chemistry. Singapura: Pearson Education South Asia Pte Ltd.

Badan Standar Nasional Pendidikan. (2006). Panduan penyusunan kurikulum tingkat satuan pendidikan jenjang pendidikan dasar dan menengah. Jakarta: BSNP.

Chemistry Insight 'O' Level 2nd Edition. (2007). Singapura: Pearson Education South Asia Pte Ltd. Depdiknas. (2006). Pedoman memilih dan meyusun bahan ajar. Jakarta: Depdiknas.

Depdiknas. (2008). Panduan pengembangan bahan ajar. Jakarta: Depdiknas.

Depdiknas. (2008). Panduan pengembangan materi pembelajaran. Jakarta: Depdiknas.

Depdiknas. (2009). Panduan penyelenggaraan program rintisan SMA bertaraf internasional (R-SMABI). Jakarta: Depdiknas.

Dick, W \& Carey, L. (1978). The systematic design of instruction. United States of America: Foresman and Company.

Earl, B \& Wilford, L.D.R. (2006). IGCSE Chemistry. Dubai: Wearset Ltd.

Effendy. (2007). A-level chemistry for senior high school students volume 2A. Malang: Bayumedia Hanafie, I. (2007). Plus minus kurikulum tingkat satuan pendidikan (KTSP), (Online). Diambil 24 Oktober 2010, dari (http://infopendidikankita.blogspot.com/2009/04/plus-minus-kurikulumtingkat-satuan.html.

Harwood, R. (2008). New edition chemistry. Dubai: Oriental Press.

Harwood, W.S., \& McMahon, M.M. (1997). Effects of integrated video media on student achievement and attitudes in high school chemistry. Journal of research In science teaching, 34(6), 617631.

Justiana, S., \& Muchtaridi. (2006). Chemistry for senior high school. Jakarta: Yudhistira. Mc. Murry, J., \& Fay, C.R. (2006). Chemistry fourth edition. United States: Prentice Hall. Rachmawati, M., \& Johari, J.M.C. (2006). Kimia SMA dan MA untuk kelas XI. Jakarta: ESIS. Ramsden, E.N. (2000). A-level chemistry fourth edition. Cheltenham: Nelson Thornes.

Thiagarajan, S., Semmel, D.G., \& Semmel, M. I. (1974). Instructional development for training teachers of exceptional children: A Sourcebook. Indiana: Center for Innovation in Teaching the Handicapped.

Trianto. (2010). Mendesain model pembelajaran inovatif-progresif. Jakarta: Kencana.

Trowbridge, L.W. (1990). Becomong a secondary school science teacher. Ohio: Merrill Publishing Company. 
Tuckman, B.W. (1978). Conducting educational research. United States: Harcout Brace Jovanovich, Inc.

Yuliati, L., Dasna, W., \& Sulissetijono. (2011). Bahan ajar IPA terpadu untuk meningkatkan kemampuan berpikir tingkat tinggi siswa SMP. Jurnal pendidikan dan pembelajaran, 18(1), 107-114. 